\title{
21. EARLY PLIOCENE DEEP-WATER CIRCULATION: STABLE ISOTOPE EVIDENCE FOR ENHANCED NORTHERN COMPONENT DEEP WATER ${ }^{1}$
}

\author{
Katharina Billups, ${ }^{2}$ A. Christina Ravelo, ${ }^{3}$ and James C. Zachos ${ }^{2}$
}

\begin{abstract}
High resolution benthic (Cibicidoides spp.) stable isotope and percent sand fraction records were constructed for the early Pliocene (3.3-4.7 Ma) at Ocean Drilling Program (ODP) Sites 925 (3042 m water depth) and 929 (4361 m water depth). These sites are located in the modern mixing zone of North Atlantic Deep Water (NADW) and Antarctic Bottom Water (AABW). We evaluate changes in deep-water circulation between the two sites using the vertical stable isotope gradient. The oxygen isotope records of both sites have well defined maxima that correspond to established glacial isotope stages for this time interval. Between 4.2 and $3.7 \mathrm{Ma}$, average $\delta^{18} \mathrm{O}$ values from the shallower Site 925 are higher than at the deeper Site 929 by $0.2 \%$, indicating that NADW may have been relatively warm and salty compared to today. Site $929 \delta^{18} \mathrm{O}$ values correspond well to previously published records, suggesting an average decrease in the isotopic composition of ocean water of $\sim 0.4 \%$ with respect to the late Holocene. At the deeper Site 929 , there is considerable $\delta^{13} \mathrm{C}$ variability with extremely low minima. These results indicate that Site 929 was highly sensitive to changes in the relative flux of northern vs. southern component deep water. Site 929 $\delta^{13} \mathrm{C}$ minima coincide with glacial stages suggesting a deep-water circulation link similar to that observed during the late Pliocene/Pleistocene. At Site $925, \delta^{13} \mathrm{C}$ values are consistently high and minima can be entirely accounted for by global $\delta^{13} \mathrm{C}$ variability. These data indicate a relatively strong NADW flux and suggest that the shallower Site 925 remained within the core of NADW throughout the majority of the time interval. The prevailing influence of northern component deep water evident at these sites is consistent with climate models that attribute early Pliocene warmth to increased northward heat transport.
\end{abstract}

\section{INTRODUCTION}

A general consensus has emerged that the early Pliocene ( $\sim 3-5$ Ma), was an interval of relative global warmth (e.g., Crowley, 1991; Kennett and Hodell, 1993). Microfaunal evidence suggests that during the early Pliocene ( $3 \mathrm{Ma}$ ), northern Atlantic sea surface temperatures may have been up to $8^{\circ} \mathrm{C}$ higher than today (Dowsett and Poore, 1991; Dowsett et al., 1992). Terrestrial evidence exists that the Antarctic continent may have been partially deglaciated (Webb and Harwood, 1991). Although evidence for the latter remains questionable (Burckle et al., 1996), the evidence for higher sea surface temperatures in the North Atlantic is fairly robust.

High-latitude warmth can be explained by several mechanisms, including higher atmospheric $\mathrm{CO}_{2}$ levels and/or more vigorous thermohaline circulation relative to today (e.g., Crowley, 1991). However, these two mechanisms appear to be somewhat mutually exclusive. Atmospheric climate models, for example, suggest that high $\mathrm{pCO}_{2}$ weakens thermohaline circulation by concentrating precipitation over the North Atlantic (e.g., Washington and Meehl, 1989). Ocean circulation models suggest that an open Panamanian Seaway (until 3-4 Ma) weakens thermohaline circulation by allowing low salinity Pacific water into the North Atlantic (e.g., Maier-Raimer et al., 1990). The geologic record, on the other hand, shows evidence of a vigorous conveyor belt in the early Pliocene that weakened as a response to the onset of northern hemisphere glaciation (e.g., Hodell and Ciesielski, 1990; Raymo et al., 1992; Raymo et al., 1996). In this study, we reconstruct deep-water circulation to determine the presence or absence of northern component deep water ( $\mathrm{NCW}$ ) in the early Pliocene Atlantic Ocean. Our results should help resolve the controversies of early Pliocene climate change and may constrain mechanisms responsible for North Atlantic warmth.

${ }^{1}$ Shackleton, N.J., Curry, W.B., Richter, C., and Bralower, T.J. (Eds.), 1997. Proc. ODP, Sci. Results, 154: College Station, TX (Ocean Drilling Program).

${ }^{2}$ Earth Sciences Department, University of California, Santa Cruz, CA 95064, U.S.A. kbillups@earthsci.ucsc.edu

${ }^{3}$ Marine Sciences, University of California, Santa Cruz, CA 95064, U.S.A.
To reconstruct changes in the vertical distribution of deep water during the early Pliocene, we have generated two benthic stable isotope stratigraphies along a depth transect on the Ceara Rise (Leg 154, Fig. 1) for the time interval of 3.3-4.7 Ma. In the deep western equatorial Atlantic, North Atlantic Deep Water (NADW) and Antarctic Bottom Water (AABW) meet and mix in proportions relative to the strength of their formation at the source areas. Today, the $\delta^{13} \mathrm{C}$ of $\Sigma \mathrm{CO}_{2}$ corresponding to the depth transect decreases from $\sim 0.97 \%$ at $3000 \mathrm{~m}$ to $\sim 0.59 \%$ at $4400 \mathrm{~m}$ (Sites 925 and 929, respectively; GEOSECS Stations 39-46, Kroopnick, 1985; Table 1; Fig. 2). This gradient reflects the predominance of NADW at the shallower site and increased influence of AABW at the deeper site $\left(\delta^{13} \mathrm{C}_{\mathrm{NADW}}=1.1 \%\right.$ vs. $\delta^{13} \mathrm{C}_{\mathrm{AABW}}=0.3 \%$; Curry et al., 1988). Not only the $\delta^{13} \mathrm{C}$ of $\Sigma \mathrm{CO}_{2}$, but also the concentration of dissolved oxygen and $\Sigma \mathrm{CO}_{2}$ change drastically at $\sim 4000 \mathrm{~m}$ indicating increased mixing with nutrient-rich water with depth in the water column below $4000 \mathrm{~m}$ (Fig. 2). We use the variability in the $\delta^{13} \mathrm{C}$ signal of benthic foraminifers from different depths within the modern mixing zone between NADW and AABW to reconstruct the relative contribution of each deep-water mass and hence its relative production rate for the early Pliocene. The presence or absence of NCW may be used to infer changes in northward heat transport in the early Pliocene Atlantic.

\section{MATERIAL AND METHODS}

High resolution ( $\sim 3000$ k.y.) benthic stable isotope stratigraphies were constructed using samples collected at $10-\mathrm{cm}$ intervals. The benthic stratigraphies represent means of single shell measurements on Cibicidoides wuellerstorfi, Cibicidoides kullenbergi, and Cibicides corpulentus picked from the $>250-\mu \mathrm{m}$ size fraction. In the majority of the intervals, multiple measurements were made on individual specimens to obtain a measure of the intraspecific and interspecific variability. In constructing the stratigraphies, all values were then averaged from a given stratigraphic level (Appendix A).

In preparation for stable isotope analysis, all shells were cleaned ultrasonically in methanol to remove adhering particles, gently bro- 


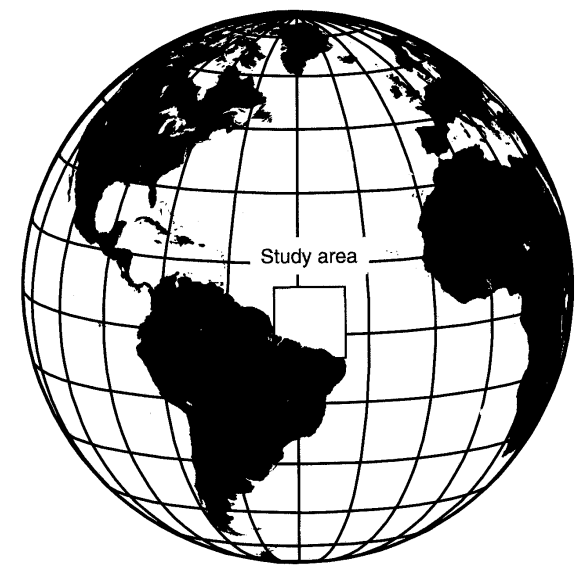

Leg 154 Site Locations

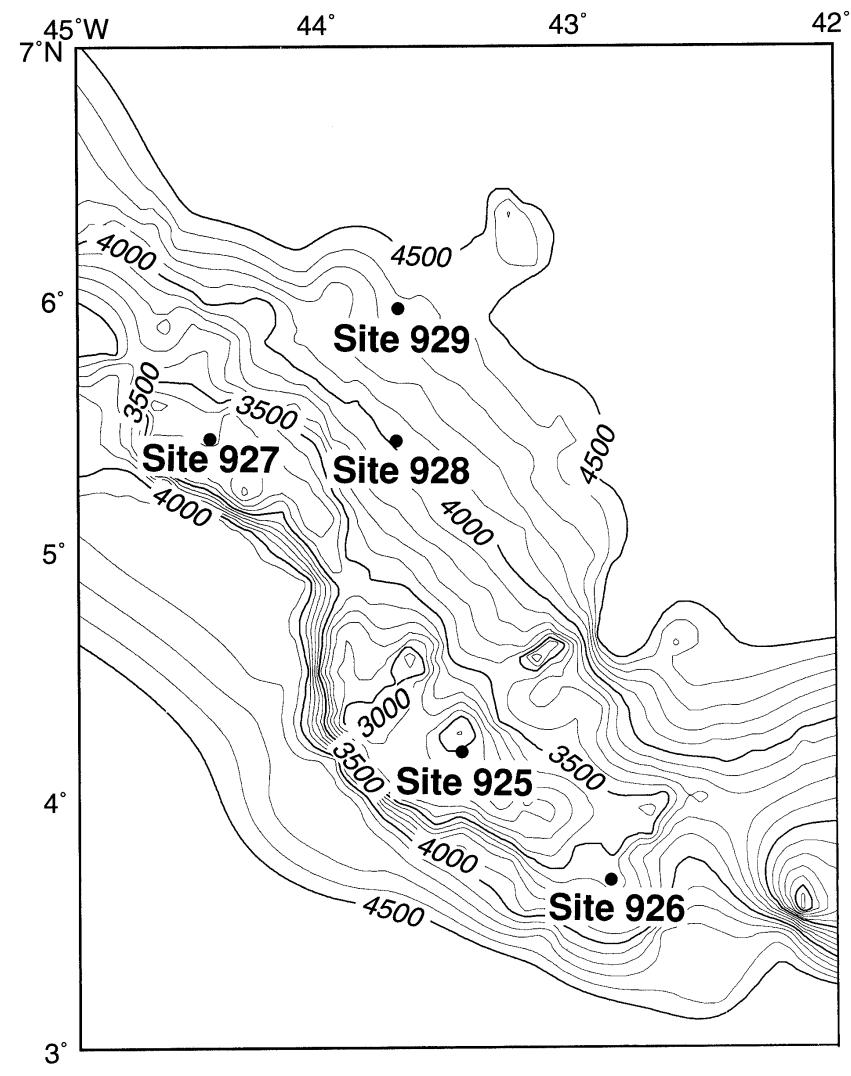

Figure 1. Core locations along the Ceara Rise depth transect (ODP Leg 154). Sites 925 and 929 investigated in this study are 3042 and 4361 meters below sea level (mbsl), respectively (Table 1). ken into smaller pieces to ensure complete reaction, and roasted under vacuum at $375^{\circ} \mathrm{C}$ for $1 \mathrm{hr}$ to oxidize organic contaminants. Stable isotope analyses were conducted using a VG Prism instrument equipped with a common acid bath at $90^{\circ} \mathrm{C} . \delta^{13} \mathrm{C}$ and $\delta^{18} \mathrm{O}$ values are calibrated to Peedee belemnite via NBS-19 and an in-house standard (Carerra marble). Based on replicate analyses of standards in the size range of the samples, our measurement precision is better than $0.05 \%$ o for $\delta^{13} \mathrm{C}$ and $0.08 \%$ or $\delta^{18} \mathrm{O}(n=280)$.

Various studies have shown that $C$. wuellerstorfi and $C$. kullenbergi have similar isotopic values (e.g., Woodruff et al., 1980; Duplessy et al., 1984; Graham et al., 1988; Farrell, 1991). Our results agree with these findings in that the difference between $C$. wuellerstorfi and C. kullenbergi is on average no more than $0.2 \%$ (Table 2). Furthermore, the average difference between $C$. wuellerstorfi and $C$. corpulentus $\delta^{13} \mathrm{C}$ and $\delta^{18} \mathrm{O}$ duplicate values is also less than $0.2 \%$ (Table 2).

A number of studies have shown that the $\delta^{18} \mathrm{O}$ value of $C$. wuellerstorfi is depleted by $0.64 \%$ with respect to equilibrium values, whereas its $\delta^{13} \mathrm{C}$ values reflect the $\delta^{13} \mathrm{C}$ of $\Sigma \mathrm{CO}_{2}$ (e.g., Shackleton et al., 1973; Shackleton and Hall, 1984; Hodell and Venz, 1992). In this study, we are only concerned about between-site gradients and use the measured, uncorrected $\delta^{18} \mathrm{O}$ data.

As a frame of reference, we compare our Pliocene $\delta^{13} \mathrm{C}$ and $\delta^{18} \mathrm{O}$ records with published late Holocene benthic values from other cores collected at the Ceara Rise (Curry et al., 1988). Sites 925 (3042 m) and $929(4361 \mathrm{~m})$ are compared to late Holocene measurements from KNR110-75 (3063 m) and KNR110-58 (4341 m), respectively (Curry et al., 1988; Table 1).

\section{STRATIGRAPHY}

The Early Pliocene sediments at Sites 925 and 929 are composed primarily of a clayey nannofossil ooze with foraminifers (Curry, Shackleton, Richter, et al., 1995). The primary difference in lithologies between the two sites is in carbonate content, which averages $\sim 70 \%$ at the shallower Site 925 and 30\% at the deeper Site 929 (Curry, Shackleton, Richter, et al., 1995). After the age model was applied (Tiedemann and Franz, this volume), Site 925 sedimentation rates ranged between 20 and $40 \mathrm{~m} / \mathrm{m}$.y., and Site 929 sedimentation rates ranged between 10 and $36 \mathrm{~m} / \mathrm{m}$.y. (Table 1 ). No evidence of significant sediment redeposition, reworking, or slumping was found at either site.

\section{Age Models}

Both sedimentary sequences exhibit marked cyclic variations in color reflectance and magnetic susceptibility that mainly reflect variations in calcium carbonate content. This cyclicity is present in all sites drilled during Leg 154 and is clearly orbital in nature. The tuned susceptibility records serve as the primary means of age control for these sites (Tiedemann and Franz, this volume).

The magnetic susceptibility record from Site 926 was tuned to the northern hemisphere insolation curve, and all sites were then corre-

Table 1. Stratigraphic and core-top information.

\begin{tabular}{clccccc}
\hline Site & \multicolumn{1}{c}{ Location } & $\begin{array}{c}\text { Water } \\
\text { depth } \\
(\mathrm{m})\end{array}$ & $\begin{array}{c}\text { Sedimentation } \\
\text { rate } \\
(\mathrm{cm} / \mathrm{k} . \mathrm{y} .) \dagger\end{array}$ & $\begin{array}{c}\delta^{18} \mathrm{O}^{*} \\
(\%)\end{array}$ & $\begin{array}{c}\delta^{13} \mathrm{C}^{*} \\
(\%)\end{array}$ & $\begin{array}{c}\delta^{13} \mathrm{C} \text { of } \\
\Sigma \mathrm{CO}_{2} \dagger \dagger \\
(\%)\end{array}$ \\
\hline 925 & $4^{\circ} 12^{\prime} \mathrm{N}, 43^{\circ} 29^{\prime} \mathrm{W}$ & 3042 & $2.2-3.0$ & & & 0.97 \\
929 & $5^{\circ} 58^{\prime} \mathrm{N}, 43^{\circ} 44^{\prime} \mathrm{W}$ & 4361 & $1.0-3.6$ & & & 0.59 \\
$\mathrm{KNR} 110-75$ & $4^{\circ} \mathrm{N}, 43^{\circ} \mathrm{W}$ & 3063 & 3.6 & $2.46 \pm 0.12$ & $0.97 \pm 0.25$ & \\
KNR110-58 & $5^{\circ} \mathrm{N}, 43^{\circ} \mathrm{W}$ & 4341 & 3 & $2.62 \pm 0.16$ & $0.62 \pm 0.21$ & \\
849 & $0^{\circ} 11^{\prime} \mathrm{N}, 110^{\circ} 31^{\prime} \mathrm{W}$ & 3851 & $2.5-3.0$ & 3.02 & 0.21 & \\
\hline
\end{tabular}

Notes: * = late Holocene Cibicidoides measurements by Curry et al. (1988) for KNR110-75 and KNR110-58 and by Mix et al. (1995) for Site 849. The $\delta^{18}$ O data is not corrected for disequilibrium. $\dagger=$ Sedimentation rates for Site 925 and 929 refer to the tuned record (Tiedemann and Franz, this volume). $\dagger \dagger=$ GEOSECS station $39-46$ (Kroopnick, 1985). 

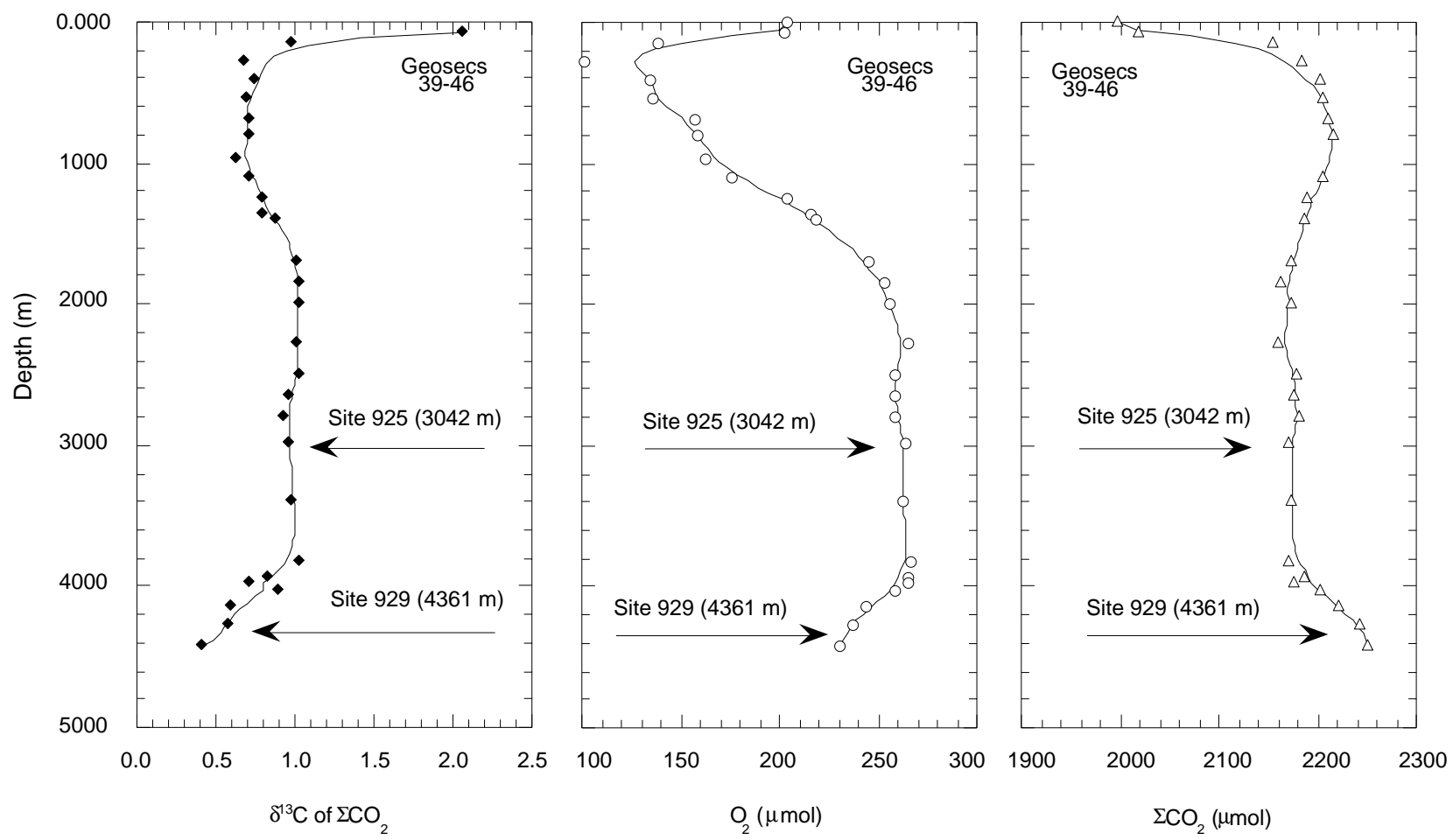

Figure 2. $\delta^{13} \mathrm{C}$ of $\Sigma \mathrm{CO}_{2}$ and concentrations of dissolved $\mathrm{O}_{2}$ and $\Sigma \mathrm{CO}_{2}$ at GEOSECS Station 39-46 in the western equatorial Atlantic (Kroopnick, 1985). Arrows point to the depth of core locations with respect to the water-column profiles. The $\delta^{13} \mathrm{C}$ of $\Sigma \mathrm{CO}_{2}$ data is also given in Table 1.

Table 2. Average difference in $\delta^{13} \mathrm{C}$ and $\delta^{18} \mathrm{O}$ values between species of Cibicidoides.

\begin{tabular}{|c|c|c|c|}
\hline Site & Species & $\begin{array}{c}\Delta \delta^{13} \mathrm{C} \text { average } \pm 1 \mathrm{~s} \\
(\% \text { o })\end{array}$ & $\begin{array}{c}\Delta \delta^{18} \mathrm{O} \text { average } \pm 1 \mathrm{~s} \\
(\% \text { o })\end{array}$ \\
\hline \multirow[t]{2}{*}{925} & $\begin{array}{l}\text { C. wuellerstorfi- } \\
\text { C. corpulentus }\end{array}$ & $0.17 \pm 0.33(\mathrm{n}=20)$ & $0.04 \pm 0.14(n=20)$ \\
\hline & $\begin{array}{l}\text { C. wuellerstorfi- } \\
\text { C. kullenbergi }\end{array}$ & $-0.09 \pm 0.21(\mathrm{n}=32)$ & $-0.22 \pm 0.25(n=32)$ \\
\hline \multirow[t]{2}{*}{929} & $\begin{array}{l}\text { C. wuellerstorfi- } \\
\text { C. corpulentus }\end{array}$ & $-0.06 \pm 0.32(\mathrm{n}=16)$ & $-0.10 \pm 0.32(n=16)$ \\
\hline & $\begin{array}{l}\text { C. wuellerstorfi- } \\
\text { C. kullenbergi }\end{array}$ & $-0.04 \pm 0.32(n=40)$ & $-0.07 \pm 0.33(n=40)$ \\
\hline
\end{tabular}

lated to Site 926 to derive ages from 0 and 5 Ma (Tiedemann and Franz, this volume). We use this age model to relate meters composite depth (mcd) to age. Following Tiedemann and Franz (this volume), we have recalculated the mcd at both sites by subtracting 2.10 $\mathrm{m}$ from the mcd at Site 925 and adding $1.04 \mathrm{~m}$ to the mcd for Site 929 (mcd* in Appendix A). We did not refine site-to-site correlations using the $\delta^{18} \mathrm{O}$ records because discrepancies between the sites are very minor, as discussed below.

\section{Oxygen Isotope Stages}

Oxygen isotope variability in early Pliocene records is distinct and can be thought of in terms of well-defined isotope stages signifying global climate change (see discussion by Shackleton et al., 1995). In the most recent numbering scheme, Shackleton et al. (1995) designate magnetic reversals with corresponding capital letters and glacial intervals with even numbers. Numbering of the isotope stages is reinitialized at each chron boundary. We follow the numbering suggested by Shackleton et al. (1995).

To determine the presence of oxygen isotope stages in our records, we compare Sites 925 and $929 \delta^{18} \mathrm{O}$ records to eastern equa- torial Atlantic Site 659 (Fig. 3), which is strongly correlated to Pacific Site 846 (Tiedemann et al., 1994). We offset the Site 929 record by $0.9 \%$ and the Site 659 record by $+1.8 \%$ relative to the Site 925 record for ease of visual correlation.

Western equatorial Atlantic Sites 925 and 929 display a series of maxima that can be visually correlated to most of the early Pliocene isotope Stages M2 through NS4 (3.3-4.7 Ma; Fig. 3). Whereas we cannot distinctly recognize Stage Gi10 at either Ceara Rise site, Stages Gi20 and Gi22 are present at the deeper Site 929, as is Stage MG6, which is not a prominent feature in the Site 659 record. Small but consistent discrepancies between Sites 925 and $659 \delta^{18} \mathrm{O}$ peaks become evident in the older part of the record. Isotope Stages N4, N6, N8, and NS2 at Site 659 appear to lead maxima at Site 925 by approximately 10,000 yr. This discrepancy is consistent with the difference between the astronomical solutions that were used to derive age models for Site 659 (Tiedemann et al., 1994) and Site 925 (Tiedemann and Franz, this volume). Because of the excellent agreement in the timing of isotope stages between the Ceara Rise records, no attempt was made to improve site-to-site correlations using the $\delta^{18} \mathrm{O}$ stratigraphies. At the deeper Site 929, age control is poor between 4.3 and 4.55 Ma (Tiedemann and Franz, this volume), introducing a high degree of uncertainty in peak-to-peak correlations. However, for the purposes of this study, the small discrepancies between absolute ages of the two sites after 4.3 Ma are inconsequential.

\section{RESULTS}

Both benthic $\delta^{18} \mathrm{O}$ and $\delta^{13} \mathrm{C}$ records for Sites 925 and 929 contain a high degree of variability (Fig. 4). This variability includes several maxima and minima defined by only a single datum point. To make more meaningful reconstructions of site-to-site gradients, we have calculated three-point running means of the data (Fig. 5). The smoothed data present a coherent picture and serve as the basis for further data interpretation. 


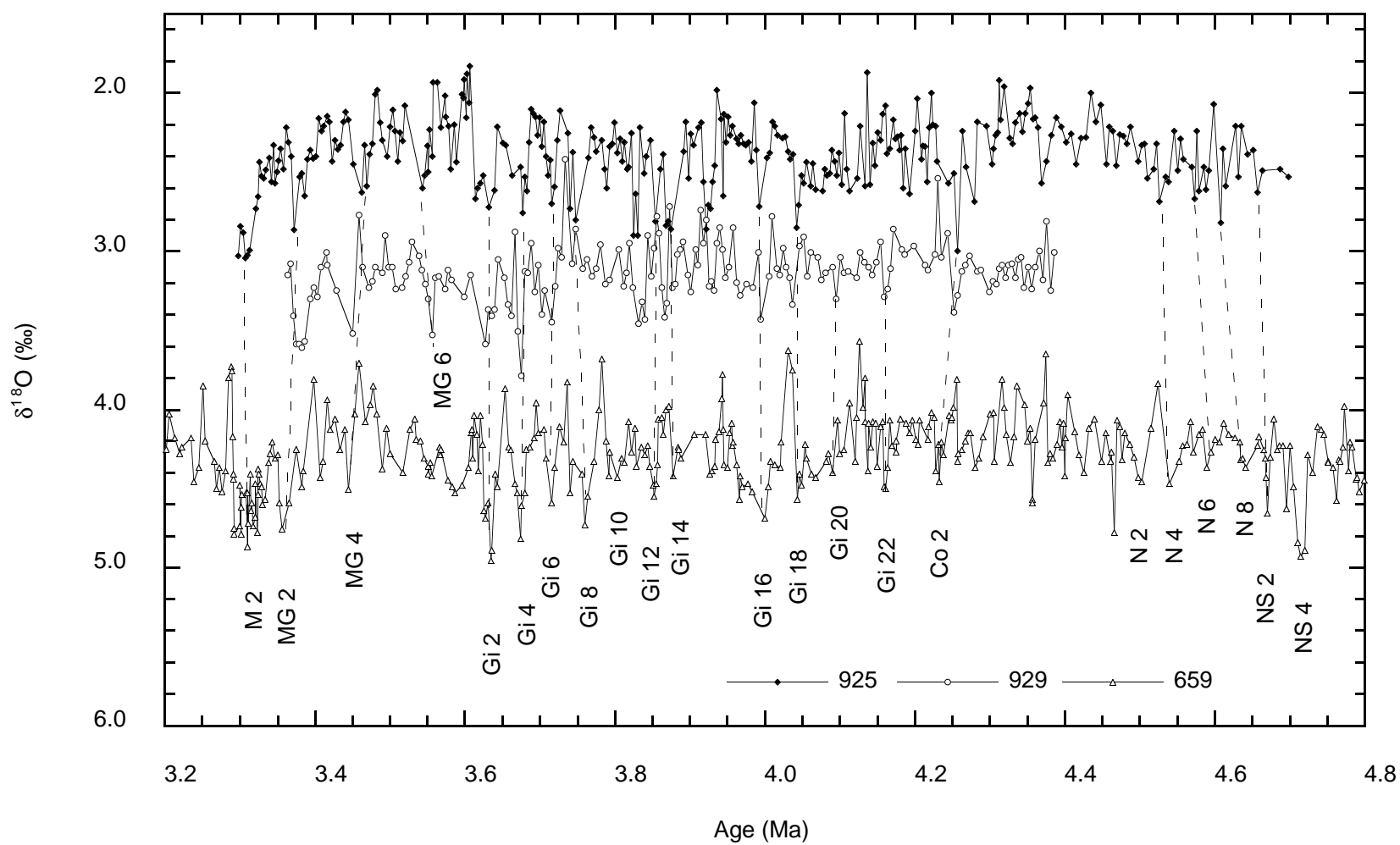

Figure 3. Oxygen isotope records of western equatorial Atlantic Sites 925 and 929 and eastern Atlantic Site 659 (Tiedemann et al., 1994). Numbers refer to glacial isotope stages established by Shackleton et al. (1995). The Site 929 record has been offset by $0.9 \%$ and the Site 659 record by $+1.8 \%$ relative to the Site 925 record. The vertical, dashed lines represent visual correlation of $\delta^{18} \mathrm{O}$ maxima between the three records.

\section{Oxygen Isotope Results}

The Sites 925 and $929 \delta^{18} \mathrm{O}$ comparison shows several prominent trends through the early Pliocene (Fig. 5A). First, in the oldest part of the records (4.4-4.3 Ma), $\delta^{18} \mathrm{O}$ values from the two sites essentially overlap. As mentioned above, poor age control would make a more detailed comparison inappropriate. Second, between 4.3 and 3.7 Ma, the $\delta^{18} \mathrm{O}$ gradient between the two sites is reversed relative to the late Holocene as discussed below (Fig. 5A). Third, between 3.7 Ma and 3.2 Ma, the $\delta^{18} \mathrm{O}$ records overlap, displaying well-defined stepwise increases towards the present. By isotope Stage M2 (3.3 Ma), Site $925 \delta^{18} \mathrm{O}$ values have reached a maximum of $\sim 0.5 \%$ obove late Holocene, indicating that significant ice growth and/or deep-water cooling has occurred at this time.

Between 4.2 and $3.7 \mathrm{Ma}$, the shallower Site $925 \delta^{18} \mathrm{O}$ values are consistently higher than those at Site 929 . On average, Site $925 \delta^{18} \mathrm{O}$ values are higher than at Site 929 by $0.2 \%$ (Table 3) and several maxima in the Site $925 \delta^{18} \mathrm{O}$ record exceed late Holocene values by as much as $\sim 0.4 \%$, whereas Site 929 maxima remain well below the late Holocene reference line. Furthermore, minimum $\delta^{18} \mathrm{O}$ values at Site 925 are only $\sim 0.3 \%$ o lower than late Holocene, but at Site 929 , lowest $\delta^{18} \mathrm{O}$ values are as much as $0.7 \%$ o below late Holocene (Table 3), which is in excellent agreement with published records from the early Pliocene (e.g., Hodell and Venz, 1992; Shackleton et al., 1995). The relatively high $\delta^{18} \mathrm{O}$ values found at Site 925 are not recorded in the Southern Ocean or Pacific (Hodell and Venz, 1992; Shackleton et al., 1995). Only eastern Atlantic Site 659 (Tiedemann et al., 1994) has similarly high values. Therefore, North Atlantic source waters may have had significantly different temperature/salinity properties than today.

The amplitude of $\delta^{18} \mathrm{O}$ variability in the Sites 925 and 929 records increases at $3.95 \mathrm{Ma}$ (Fig. 5A). This change corresponds to a longterm, global cooling trend initiated at $4.3 \mathrm{Ma}$ and with significant growth of west Antarctic ice sheets by 3.9-3.95 Ma (Hodell et al., 1982). Oxygen isotope Stage Co2 (4.25 Ma), which is a prominent feature in both Ceara Rise records, may signal the beginning of this cooling trend. Thus, whereas the absolute values of the Site $925 \delta^{18} \mathrm{O}$ record differ from records of other oceans probably due to local temperature/salinity changes between 4.3 and 3.7 Ma, the amplitude of $\delta^{18} \mathrm{O}$ fluctuations are comparable to other records and does reflect global processes.

\section{Carbon Isotope Results}

Comparison of Sites 925 and 929 benthic $\delta^{13} \mathrm{C}$ records indicates that at $4.2 \mathrm{Ma}$, a gradient similar to the late Holocene gradient becomes established (Fig. 5B; Table 3). Prior to 4.2 Ma and corresponding to the interval of $\delta^{18} \mathrm{O}$ overlap, there is no $\delta^{13} \mathrm{C}$ gradient between the two sites. Within this time interval, $\delta^{13} \mathrm{C}$ values at the deeper Site 929 exceed late Holocene values, whereas $\delta^{13} \mathrm{C}$ values of the shallower site are lower. Both records converge towards a pronounced minimum at 4.2 Ma. After 4.2 Ma, the gradient is not stable but varies between $\sim 0.2 \%$ and $0.35 \%$. Maximum $\delta^{13} \mathrm{C}$ values at the shallower Site 925 fluctuate between $\sim 1$ and $1.2 \%$, reflecting pure NADW end member composition of $1.1 \%$ o (e.g., Curry et al., 1988). Some of the $\delta^{13} \mathrm{C}$ maxima at the deeper site are as much as $0.4 \%$ above late Holocene. During times of $\delta^{13} \mathrm{C}$ maxima at the deeper Site 929 , the vertical $\delta^{13} \mathrm{C}$ gradient between Sites 925 and 929 is smallest. On average, however, the vertical gradient is roughly $0.3 \%$, in close agreement with the late Holocene.

Extreme deviations from the average gradient are mainly the result of large amplitude $\delta^{13} \mathrm{C}$ minima at the deeper Site 929 (Fig. 5B). Here, $\delta^{13} \mathrm{C}$ values are nearly $0.8 \%$ o lower than late Holocene, whereas Site $925 \delta^{13} \mathrm{C}$ minima are only $\sim 0.4 \%$ o lower. The lowest $\delta^{13} \mathrm{C}$ values at Site 929 and the largest vertical $\delta^{13} \mathrm{C}$ gradients between Sites 925 and 929 occur at $4.05 \mathrm{Ma}, 3.75 \mathrm{Ma}, 3.67 \mathrm{Ma}, 3.63 \mathrm{Ma}$, and $3.45 \mathrm{Ma}$ 

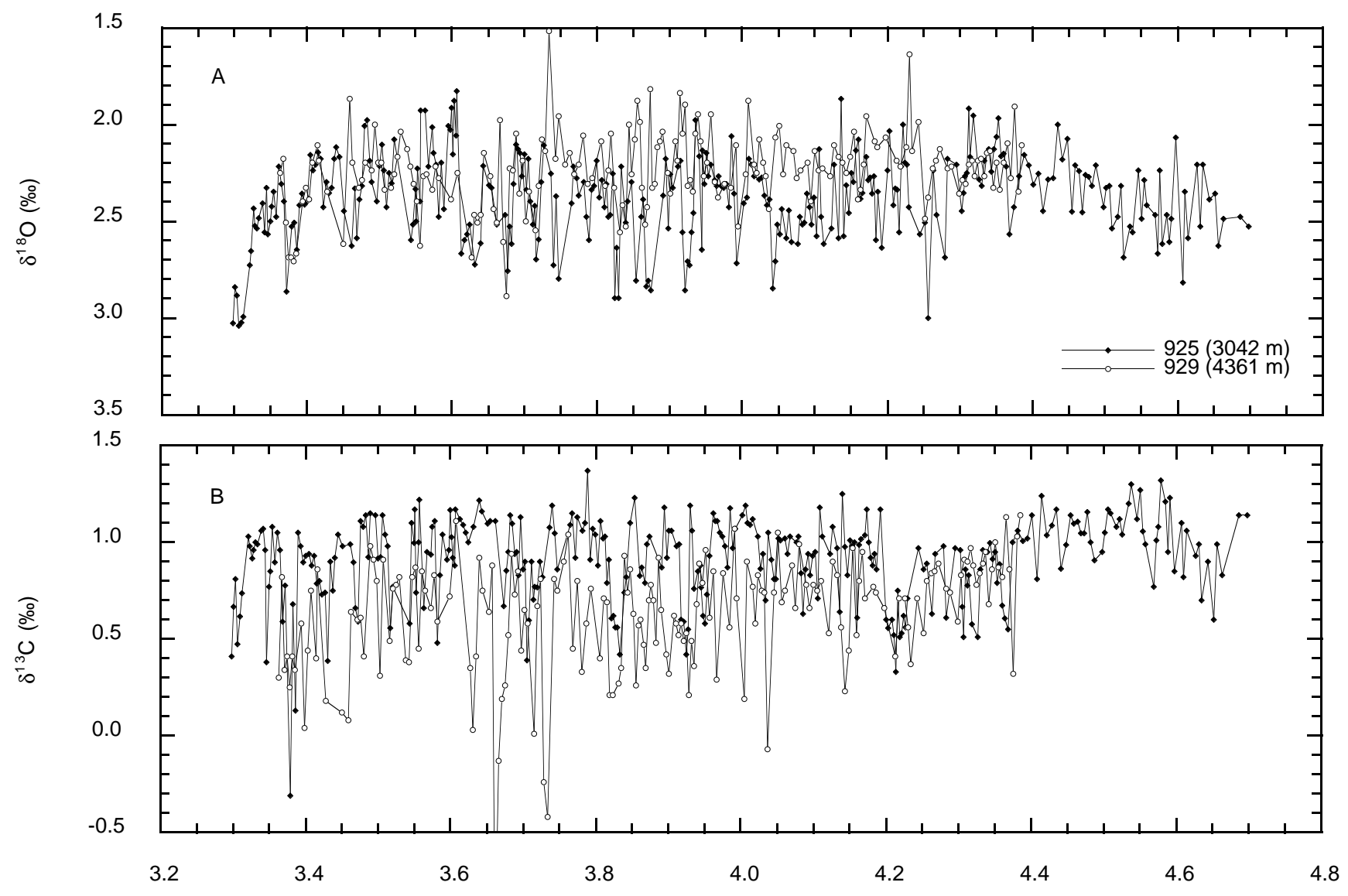

Age (Ma)

Figure 4. Benthic $\delta^{18} \mathrm{O}(\mathbf{A})$ and $\delta^{13} \mathrm{C}(\mathbf{B})$ records along the Ceara Rise depth transect for Sites 925 and 929 . The stratigraphies are constructed from single shell measurements of Cibicidoides spp. and then averaged (see text).

(Fig. 5B), corresponding to glacial Stages Gi18, Gi8, Gi4, Gi2, and MG4, respectively (Fig. 3).

Between 3.7 and 3.3 Ma, $\delta^{13} \mathrm{C}$ values from both sites are generally lower than in the older parts of the records (Table 3). At Site 925, an extreme $\delta^{13} \mathrm{C}$ minimum occurs during isotope Stage MG2 (3.4 Ma). At this time, the Site $925 \delta^{13} \mathrm{C}$ amplitude is comparable to that of the last glacial to interglacial cycle in the western equatorial Atlantic at a water depth of $3000 \mathrm{~m}(0.69 \%$; Curry et al., 1988). Furthermore, during Stage MG2, the vertical $\delta^{13} \mathrm{C}$ gradient is diminished. We note that this is the first occurrence of a lack of a significant vertical gradient during a glacial event since 4.2 Ma.

\section{DISCUSSION}

\section{Early Pliocene Deep-Water Circulation}

Changes in the relationship between benthic foraminiferal $\delta^{13} \mathrm{C}$ and $\delta^{18} \mathrm{O}$ records reflect in part changes in the dominant water masses flowing into the deep western equatorial Atlantic through time. For example, Late Pliocene/Pleistocene circulation in the deep Atlantic is characterized by the presence of a nutrient-depleted water mass of northern Atlantic origin during interglacial intervals (e.g., Oppo et al., 1990; Raymo et al., 1990). As a result, relatively high benthic foraminiferal $\delta^{13} \mathrm{C}$ values are recorded during times of low $\delta^{18} \mathrm{O}$ values. During glacials (high $\delta^{18} \mathrm{O}$ ), $\delta^{13} \mathrm{C}$ values are lower, reflecting mixing with a more nutrient-rich water mass originating in the Southern Ocean (e.g., Boyle and Keigwin, 1987; Curry et al., 1988; Raymo et al., 1990; Oppo et al., 1990; Oppo et al., 1995). As we will show, lo- cal deep-water circulation changes at the Ceara Rise appear to dominate the early Pliocene $\delta^{13} \mathrm{C}$ signal at the deeper Site 929 on glacial to interglacial time scales.

\section{2-4.7 Ma}

There is a general trend of decreasing $\delta^{13} \mathrm{C}$ and decreasing $\delta^{18} \mathrm{O}$ values towards 4.2 Ma at the shallower Site 925 (Fig. 6A). Thus, the evolution of the stable isotopic signals across this $400,000 \mathrm{yr}$ time span indicates a transition from relatively cooler climate/greater ice volume at 4.6 Ma to relatively warmer conditions/lower ice volume at 4.2 Ma that was associated with a decrease in equatorial Atlantic $\delta^{13} \mathrm{C}$ values. Cross-plotting the individual $\delta^{13} \mathrm{C}$ and $\delta^{18} \mathrm{O}$ values also indicates a weak association of higher $\delta^{13} \mathrm{C}$ values with higher $\delta^{18} \mathrm{O}$ values and vice versa at both sites (Fig. 7A). The general drift from 4.6 to $4.2 \mathrm{Ma}$ in $\delta^{13} \mathrm{C}$ and $\delta^{18} \mathrm{O}$ towards lower values as well as the relationship between individual $\delta^{13} \mathrm{C}$ and $\delta^{18} \mathrm{O}$ values suggest that a direct link between ice volume/temperature and deep-water circulation did not exist at this time. Whether the $\delta^{13} \mathrm{C} / \delta^{18} \mathrm{O}$ relationship reflects a global change in the carbon budget or a local effect of source water $\delta^{13} \mathrm{C}$ cannot be determined from the Ceara Rise data alone. We will address this issue further by making a comparison to equatorial Pacific records from Site 849 (Mix et al., 1995) in a later section.

\section{2-3.7 Ma}

Between 4.2 and 3.7 Ma, the $\delta^{13} \mathrm{C}$ and $\delta^{18} \mathrm{O}$ records at the shallower Site 925 do not covary, whereas $\delta^{13} \mathrm{C}$ and $\delta^{18} \mathrm{O}$ records at the deep- 

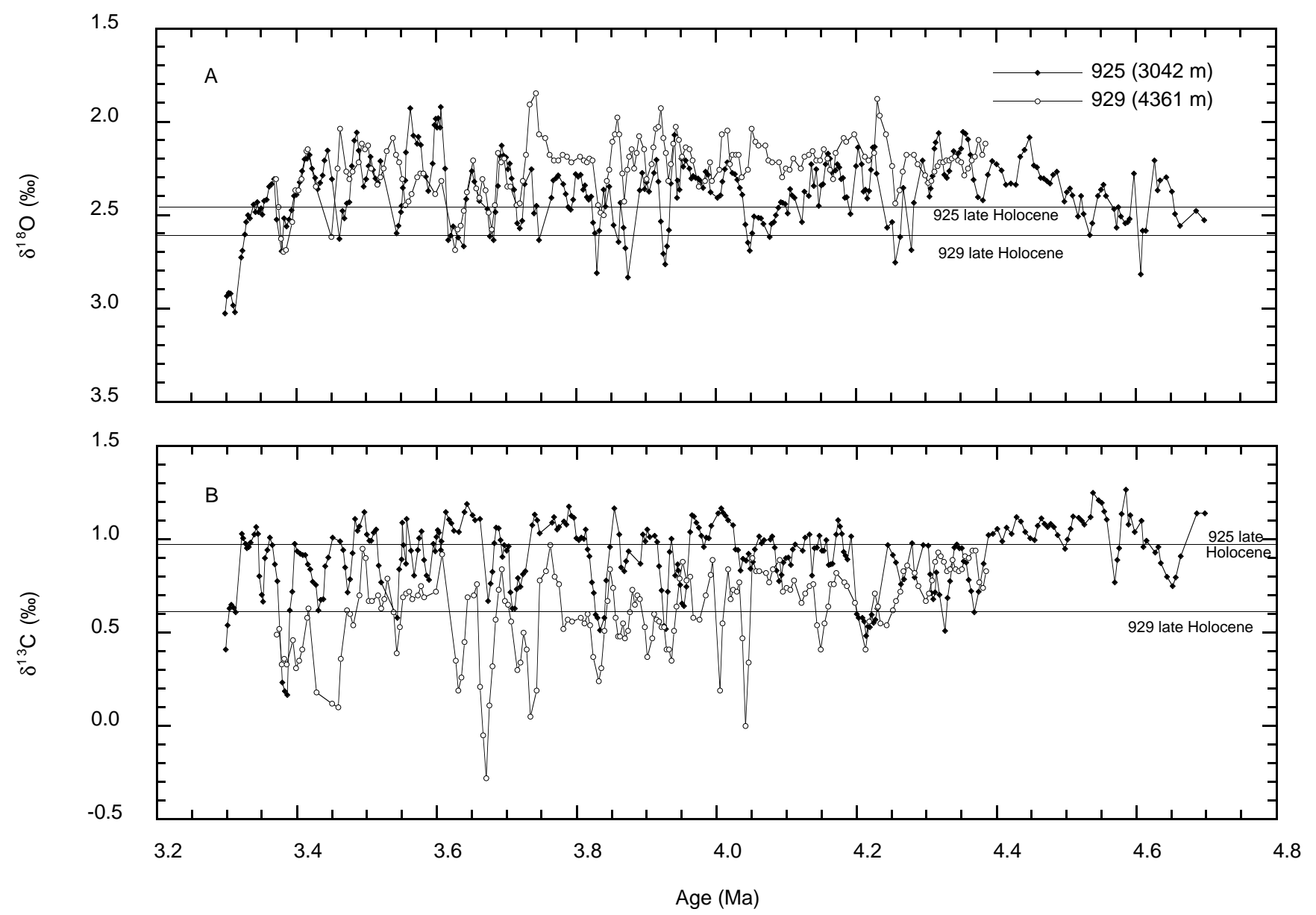

Figure 5. Benthic $\delta^{18} \mathrm{O}(\mathbf{A})$ and $\delta^{13} \mathrm{C}(\mathbf{B})$ records along the Ceara Rise depth transect for Sites 925 and 929 replotted using a three-point running mean.

Table 3. Summary of $\delta^{18} \mathrm{O}$ and $\delta^{13} \mathrm{C}$ data.

\begin{tabular}{|c|c|c|c|c|c|c|c|c|c|}
\hline \multirow[b]{2}{*}{$\begin{array}{l}\text { Time } \\
(\mathrm{Ma})\end{array}$} & \multicolumn{4}{|c|}{ Site 925} & \multicolumn{4}{|c|}{ Site 929} & \multirow{2}{*}{$\begin{array}{c}\text { Sites } 925-929 \\
\text { average vertical } \\
\text { gradient }\end{array}$} \\
\hline & $\begin{array}{c}\text { average } \\
(\% o)\end{array}$ & $\underset{(\% o)}{\operatorname{minimum}}$ & $\begin{array}{c}\underset{(\% o)}{\operatorname{maximum}}\end{array}$ & $\begin{array}{l}\text { range } \\
(\% o)\end{array}$ & $\begin{array}{c}\text { average } \\
(\% o)\end{array}$ & $\underset{(\%)}{\operatorname{minimum}}$ & $\begin{array}{l}\underset{(\% o}{\operatorname{maximum}} \\
\end{array}$ & $\begin{array}{l}\text { range } \\
(\% o)\end{array}$ & \\
\hline \multicolumn{10}{|l|}{$\delta^{18} \mathrm{O}$} \\
\hline $3.2-3.7$ & 2.39 & 1.92 & 3.03 & 1.11 & 2.35 & 2.04 & 2.70 & 0.66 & 0.04 \\
\hline $3.7-4.2$ & 2.40 & 2.07 & 2.84 & 0.77 & 2.19 & 1.85 & 2.50 & 0.65 & 0.21 \\
\hline $4.2-4.7$ & $2.35(2.29)$ & 2.06 & 2.82 & 0.76 & 2.21 & 1.88 & 2.44 & 0.56 & 0.08 \\
\hline \multicolumn{10}{|l|}{$\delta^{13} \mathrm{C}$} \\
\hline $3.2-3.7$ & 0.88 & 0.17 & 1.19 & 1.02 & 0.52 & -0.28 & 0.95 & 1.23 & 0.36 \\
\hline $3.7-4.2$ & 0.94 & 0.51 & 1.18 & 0.67 & 0.62 & 0.00 & 0.97 & 0.97 & 0.32 \\
\hline $4.2-4.7$ & $0.91(0.76)$ & 0.48 & 1.27 & 0.79 & 0.77 & 0.41 & 0.94 & 0.53 & -0.01 \\
\hline
\end{tabular}

Notes: Values in parentheses represent average $\delta^{18} \mathrm{O}$ and $\delta^{13} \mathrm{C}$ values between 4.2 and 4.4 Ma (interval of overlap of Sites 925 and 929 ; see text).

er Site 929 are closely related (Fig. 6). At the shallower Site 925, only four of the glacial events are accompanied by $\delta^{13} \mathrm{C}$ minima (Fig. 6A). At the deeper Site 929, all glacial maxima are associated with $\delta^{13} \mathrm{C}$ minima and vice versa with only one exception; the $\delta^{13} \mathrm{C}$ minimum at 3.75 Ma occurs during maximum interglacial conditions (Fig. 6B). The cross-plot of individual datum points illustrates the general lack of association between the variables at the shallower Site 925 (Fig. 7B). At the deeper Site 929, there is tendency for the lowest $\delta^{13} \mathrm{C}$ values to correspond with the highest $\delta^{18} \mathrm{O}$ values. Thus, for this time interval the stable isotope records at the deeper Site 929 indicate that the relationship between deep-water circulation and ice volume/temperature was similar to that of the late Pliocene/Pleistocene.

The lack of a late Pliocene/Pleistocene type of signal at the shallower Site 925 is largely due to the fact that $\delta^{13} \mathrm{C}$ values are not con- sistently low during glacial stages (Fig. 6A). Mixing with southern component deep water (SCW) must have been minimal at $3000 \mathrm{~m}$ water depth even during times of $\delta^{18} \mathrm{O}$ maxima (glacials). Thus, the influence of NCW was always strong. In a later section, we will show that the $\delta^{13} \mathrm{C}$ minima that do exist at Site 925 can be related to changes in the global carbon budget on these glacial to interglacial time scales. High amplitude $\delta^{13} \mathrm{C}$ variability at the deeper Site 929 , on the other hand, is related to fluctuations in the relative amount of SCW.

Consistently high $\delta^{13} \mathrm{C}$ values characteristic for this time interval provide further evidence for the presence of $\mathrm{NCW}$ in the equatorial Atlantic. About half of the $\delta^{13} \mathrm{C}$ values are higher than late Holocene values at these sites (Fig. 7B). At Site 925, many of the $\delta^{13} \mathrm{C}$ values reflect the modern end-member $\mathrm{NADW}_{\delta}{ }^{13} \mathrm{C}$ composition of $\sim 1.1 \%$ (Curry et al., 1988), and maximum $\delta^{13} \mathrm{C}$ values are even higher. At 

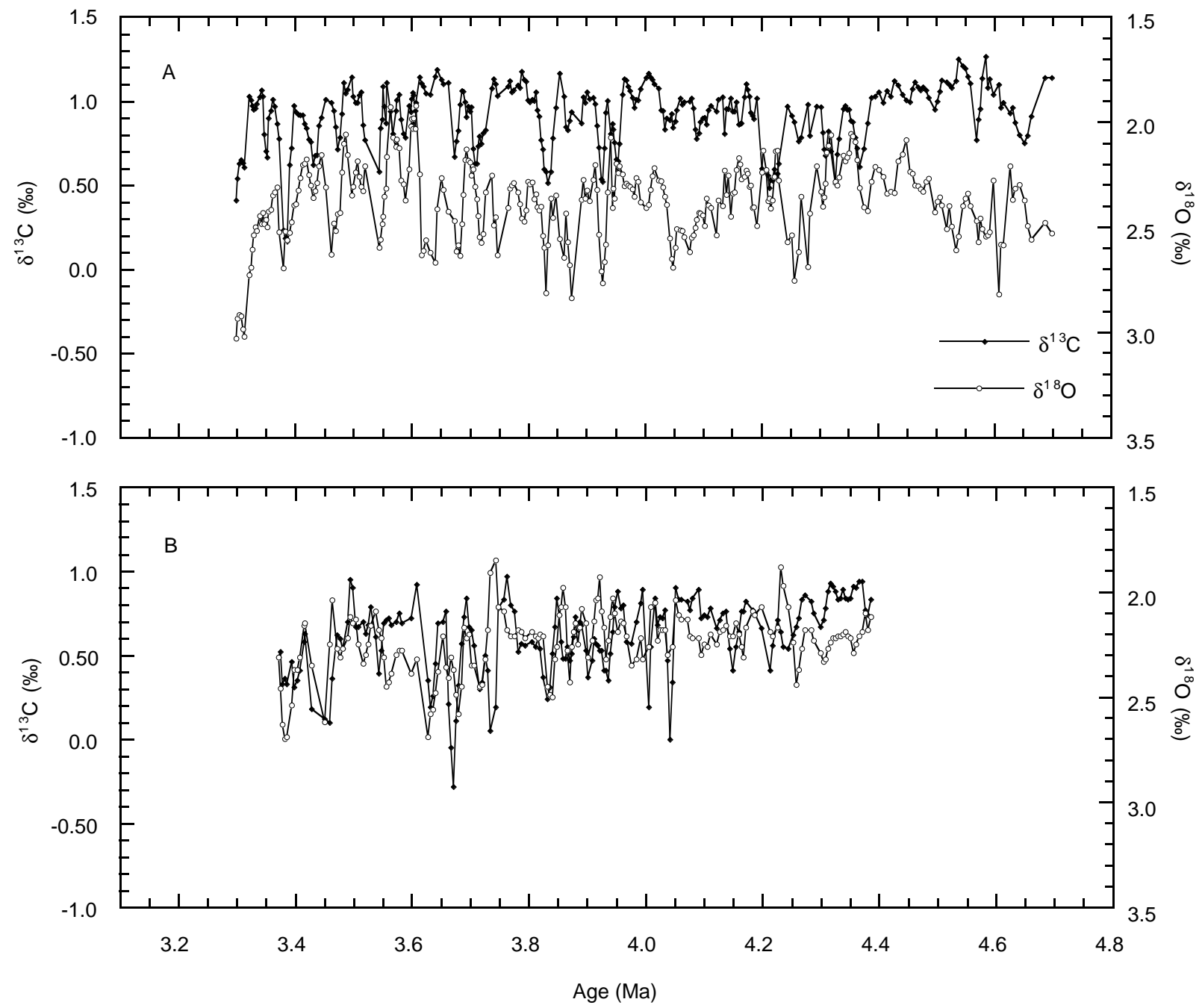

Figure 6. Comparison of $\delta^{13} \mathrm{C}$ record with $\delta^{18} \mathrm{O}$ record for Sites 925 (A) and 929 (B).

the deeper Site 929 , maximum $\delta^{13} \mathrm{C}$ values are as high as $\delta^{13} \mathrm{C}$ values at $3000 \mathrm{~m}$ water depth during the late Holocene (Fig. 5B), suggesting significantly reduced mixing with nutrient-rich water at these times. Predominantly high $\delta^{13} \mathrm{C}$ values, together with a persistent vertical $\delta^{13} \mathrm{C}$ gradient comparable to late Holocene, provide strong evidence that NCW formation prevailed during this time interval.

\section{7-3.3 Ma}

Between 3.7 and $3.3 \mathrm{Ma}, \delta^{13} \mathrm{C}$ minima consistently coincide with glacial stages at both sites (Fig. 6). Cross-plotting the variables further illustrates that in this time interval, low $\delta^{13} \mathrm{C}$ values coincide with highest $\delta^{18} \mathrm{O}$ values (Fig. 7C), suggesting that deep-water circulation is related to ice volume/temperature during this time interval. For example, Site $925 \delta^{13} \mathrm{C}$ values are extremely low during glacial Stage MG2 (3.4 Ma), reflecting an increase in mixing with nutrient-rich water at $3000 \mathrm{~m}$ water depth. The lack of a vertical $\delta^{13} \mathrm{C}$ gradient between Sites 925 and 929 at this time supports the possibility of a upward migration of the mixing zone between NCW and SCW (Fig. $5 \mathrm{~B})$. Thus, the relative flux of NADW may have decreased to below late Holocene production rates for the first time at 3.4 Ma.

Both sites also show an increased range in $\delta^{18} \mathrm{O}$ and $\delta^{13} \mathrm{C}$ values between 3.7 and 3.3 Ma with respect to the older time intervals (Table 3 ). This is most evident at the shallower Site 925. This observation is consistent with previous reconstructions; it may reflect the onset of more dramatic climate conditions associated with cooling in high northern latitudes at 3.2 Ma (e.g., Shackleton and Opdyke, 1973; Raymo et al., 1987; Kennett and Hodell, 1993; Raymo, 1994). Increased $\delta^{18} \mathrm{O}$ and $\delta^{13} \mathrm{C}$ amplitude in our records, particularly at the shallower Site 925, may indicate more variable relative deep-water formation rates at high northern latitudes prior to this cooling event. The decrease in the relative flux of NCW at $\sim 3.4$ Ma may be associated with the subsequent cooling of high northern latitudes.

\section{Additional Constraints on Early Pliocene Deep-water Circulation}

During the Pleistocene, carbonate preservation declined during times when the influence of SCW, or AABW, increased in the north Atlantic (e.g., Crowley, 1983). We would expect that in the early Pliocene there would be a similar link between dissolution and deepwater circulation. Because planktonic foraminifers are particularly dissolution susceptible, carbonate preservation can be approximated with percent coarse fraction records (particles $>63 \mu \mathrm{m}$; e.g., Bassinot, 1994; Woodruff and Savin, 1991). Thus, percent coarse fraction (percent sand size) records may provide an additional constraint on early Pliocene deep-water circulation patterns.

Percent coarse fraction records from the Ceara Rise may also be strongly influenced by clay dilution from the Amazon river. Both circulation induced changes in preservation and climate induced fluctuations in terrestrial riverine input respond in a complementary fash- 

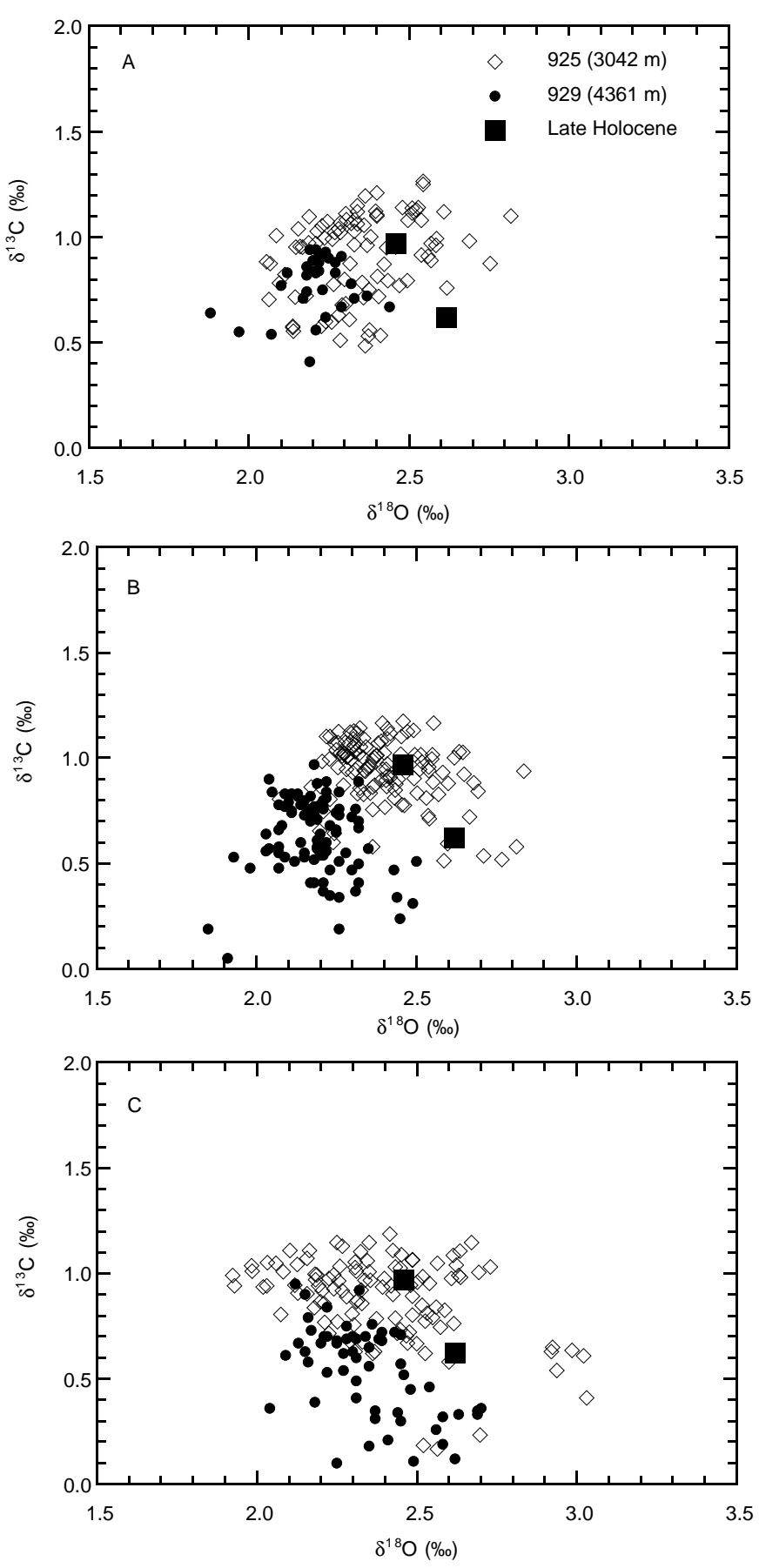

Figure 7. Cross-plots of $\delta^{18} \mathrm{O}$ vs. $\delta^{13} \mathrm{C}$ values for three discrete time intervals (see text).

ion. For example, riverine input from the Amazon increases during sea-level lowstands (Curry, Shackleton, Richter, et al., 1995) when benthic $\delta^{18} \mathrm{O}$ values are higher and preservation is lower (Crowley 1983). Because we cannot easily differentiate between dilution and preservation, we use the percent sand records only as a qualitative indicator of preservation between the two sites. Computation of mass accumulation rates (MAR) would have provided a more quantitative indicator of carbonate preservation; however, high resolution gamma ray porosity evaluator (GRAPE) data needed to compute MAR are not available for this site (Curry, Shackleton, Richter, et al., 1995).
Between 4.7 and 4.2 Ma, percent sand size and $\delta^{13} \mathrm{C}$ records decrease from 4.7 to $4.2 \mathrm{Ma}$ at both sites (Fig. 8). This pattern is typical for late Pliocene/Pleistocene circulation changes in the Atlantic when preservation improved in association with the presence of a nutrientpoor, ${ }^{13} \mathrm{C}$-enriched water mass. However, the associated decrease in $\delta^{18} \mathrm{O}$ values (Fig. 6A) suggests a shift towards lower ice-volume/ warmer conditions from 4.7 to $4.2 \mathrm{Ma}$. Thus, preservation appears to have been relatively enhanced during the higher $\delta^{18} \mathrm{O}$ interval relative to the lower $\delta^{18} \mathrm{O}$ interval, a pattern more commonly observed in the Pleistocene Pacific (e.g., Farell and Prell, 1991; Broecker and Peng, 1982). Hence deep-water circulation in the Atlantic may not be directly linked to glacial-interglacial climate variability characteristic of the late Pliocene/Pleistocene Atlantic Ocean during this time interval.

The percent sand records are consistent with the $\delta^{13} \mathrm{C}$ and $\delta^{18} \mathrm{O}$ results between 4.2 and 3.3 Ma. At the shallower Site 925 the percent sand remains relatively high consistent with the persistence of nutrient-poor, non-corrosive, ${ }^{13} \mathrm{C}$-enriched NCW (Fig. 8A). At the deeper site, percent sand maxima correspond well to $\delta^{13} \mathrm{C}$ maxima and vice versa, reflecting the varying influences of NCW (Fig. 8B). Between 3.7 and 3.2 Ma, there is a trend of decreasing percent coarse fraction, which parallels a general decrease in $\delta^{13} \mathrm{C}$ values at the shallower Site 925 (Fig. 8A), suggesting a circulation induced decrease in preservation that is also evident at the shallower Site 925 at this time. Thus, assuming that percent sand is partially controlled by preservation and dissolution, the sand fraction records support our interpretations of the stable isotope results.

\section{Atlantic-Pacific Stable Isotope Gradients Oxygen Isotope Gradients}

Comparison of the equatorial Atlantic $\delta^{18} \mathrm{O}$ stratigraphies to the Pacific record at Site 849 (Mix et al., 1995) demonstrates that some short- and long-term features are likely global in nature (Fig. 9). For example, the marked increase in $\delta^{18} \mathrm{O}$ amplitude at $3.95 \mathrm{Ma}$ at the Ceara Rise is also strongly evident at Pacific Site 849, suggesting increased magnitude of global ice-volume fluctuations in agreement with previous discussions of early Pliocene climate change (e.g., Hodell et al., 1982). Furthermore, coincident $\delta^{18} \mathrm{O}$ maxima between the three records are close to late Holocene values (e.g., at 3.65-3.7 $\mathrm{Ma}$ and 3.3 Ma) indicating that continental ice volume was as sizable as today.

Prior to $\sim 3.7 \mathrm{Ma}$, only the Site $925 \delta^{18} \mathrm{O}$ values exceed late Holocene, and Sites 929 and $849 \delta^{18} \mathrm{O}$ values remain at least $0.2 \%$ obelow late Holocene. The difference in $\delta^{18} \mathrm{O}$ values between Sites 929 and 849 is similar to the late Holocene, suggesting that the thermal gradient between the two ocean basins remained the same. Hence, the Atlantic-Pacific comparison supports our previous interpretation that the relatively high $\delta^{18} \mathrm{O}$ value at Site 925 (and Site 659) may be due to regional temperature/salinity anomalies.

Northern latitudes could provide a source for ${ }^{18} \mathrm{O}$-enriched deep water. For instance, a reversed vertical $\delta^{18} \mathrm{O}$ gradient in the Indian Ocean during the middle Miocene is consistent with the influence of warm saline waters of Tethyan origin (Woodruff and Savin, 1991). Today, Mediterranean overflow can be traced into the North Atlantic (e.g., Pickard and Emery, 1990). In the early Pliocene, there may have been a stronger relative flux of warm saline waters originating in the Mediterranean. Alternatively, warmer, more saline, ${ }^{18} \mathrm{O}$-enriched waters may have originated from subtropical gyres that extended farther north than today. Ocean general circulation models indicate that subtropical salinity and temperature anomalies can be advected north within the eastern boundary current to deep-water formation sites in the North Atlantic in agreement with modern observations (e.g., Rind and Chandler, 1991). A more northward position of the subtropical gyre during the Pliocene may explain the relatively high $\delta^{18} \mathrm{O}$ values observed at the shallower Site 925 . The ob- 


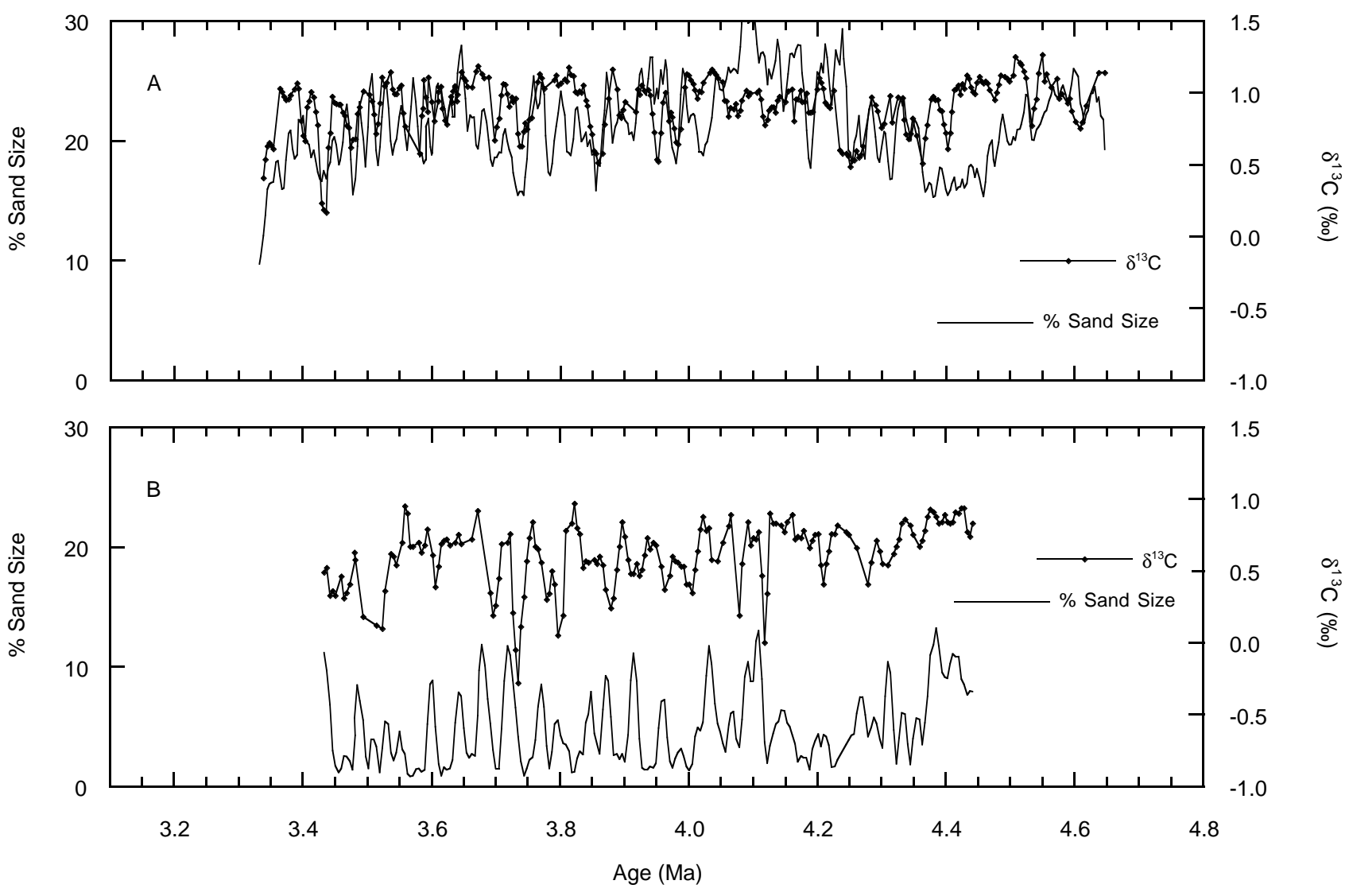

Figure 8. Comparison of percent sand and $\delta^{13} \mathrm{C}$ records from Sites 925 (A) and 929 (B).

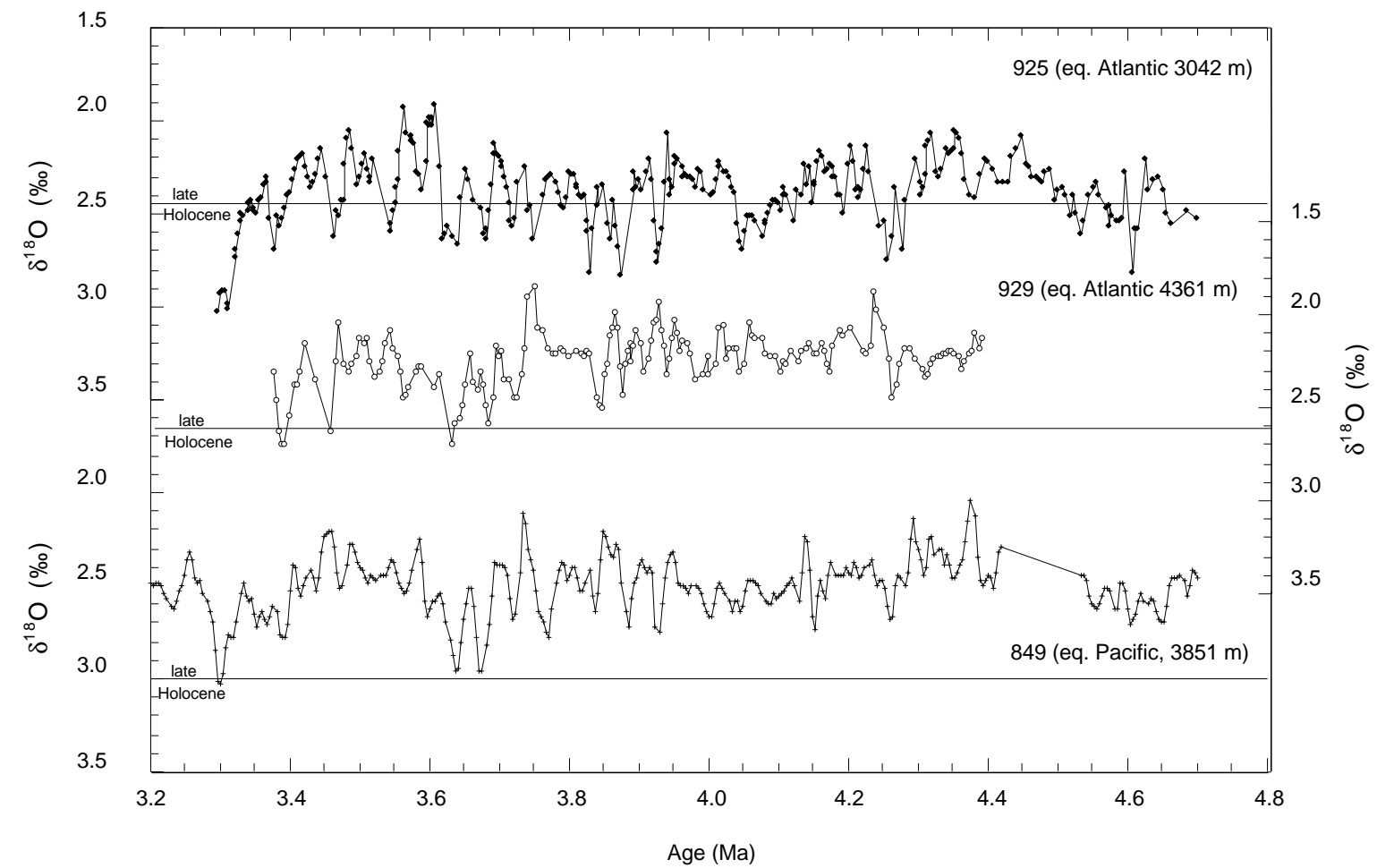

Figure 9. Horizontal $\delta^{18} \mathrm{O}$ gradients between Atlantic Sites 925, 929, and Pacific Site 849 (Mix et al., 1995). The benthic $\delta^{18} \mathrm{O}$ values from Site 849 have been "uncorrected." Site 849 has been smoothed with a 19 k.y. Gaussian filter (Mix et al., 1995). 
servation of relatively high $\delta^{13} \mathrm{C}$ values at the shallower site would also be consistent with this scenario, indicating the presence of a nutrient-depleted water mass.

\section{Carbon Isotope Gradients}

In a global context, $\delta^{13} \mathrm{C}$ values can be interpreted as a change in mean oceanic $\delta^{13} \mathrm{C}$ values due to the transfer of ${ }^{12} \mathrm{C}$-enriched carbon between terrestrial and marine environments on glacial to interglacial time scales (Shackleton, 1977). To constrain the influence of globally averaged carbon budget on the Ceara Rise sites, we also compare our $\delta^{13} \mathrm{C}$ records to Site 849 (Mix et al., 1995). This comparison provides a means of constraining the horizontal $\delta^{13} \mathrm{C}$ gradient between the two ocean basins and assessing NCW production in the Atlantic (e.g., Miller and Fairbanks, 1985; Raymo et al., 1990; Wright et al., 1991; Mix et al., 1995). For example, increased Atlantic-Pacific $\delta^{13} \mathrm{C}$ gradients reflect relatively high NCW flux, whereas low gradients reflect a relative increase in SCW flux in the deep Atlantic.

Between 4.4 and 4.2 Ma, Pacific Site 849 had $\delta^{13} \mathrm{C}$ values well below late Holocene (Fig. 10), possibly indicating that the ${ }^{13} \mathrm{C} /{ }^{12} \mathrm{C}$ ratio of mean global ocean water was lower than today. This global signal is reflected in the Site $925 \delta^{13} \mathrm{C}$ record, which also shows low values during this time span. Site $929 \delta^{13} \mathrm{C}$ values, on the other hand, are above late Holocene, indicating that factors other than global $\delta^{13} \mathrm{C}$ variability are imprinted on the deeper Atlantic record. In addition, the $\delta^{13} \mathrm{C}$ gradient between the deepest Atlantic (Site 929) and Pacific is greatest at approximately $4.4 \mathrm{Ma}$ and approaches late Holocene values by $4.2 \mathrm{Ma}$. Using the magnitude of the Atlantic-Pacific $\delta^{13} \mathrm{C}$ gradient as a measure of relative flux of NCW (Raymo et al., 1990), we conclude that NCW was relatively strong between 4.4 and $4.3 \mathrm{Ma}$, and then decreased to late Holocene rates by $4.2 \mathrm{Ma}$.

Between 4.2 and 3.7 Ma, basin-to-basin fractionation between the shallower Atlantic Site 925 and the Pacific was enhanced relative to the late Holocene (Fig. 10). All Site $925 \delta^{13} \mathrm{C}$ values are at or above late Holocene values except during the few lower $\delta^{13} \mathrm{C}$ events in the record. However, the amplitude of each Site $925 \delta^{13} \mathrm{C}$ minima is comparable to the corresponding amplitude in the Pacific record $(\sim 0.4 \%$ o). These observations suggest that minima in the Site 925 $\delta^{13} \mathrm{C}$ record can be accounted for by fluctuations in the global carbon budget. This implies that the shallower site remained within the core of NCW throughout the entire time interval between 4.2 and 3.7 Ma. Consistent with our above interpretation, Site 925 was not sensitive to changes in the relative flux of either NCW or SCW because it was continuously bathed by high $\delta^{13} \mathrm{C} \mathrm{NCW}$.

The degree of basin-to-basin fractionation between the deeper Site 929 and the Pacific Site 849 is more variable (Fig. 10) between 4.2 and 3.7 Ma. Minima in the $\delta^{13} \mathrm{C}$ record at Site 929 are often in excess of the global $0.4 \%$ orecorded in the Pacific and even approach $\mathrm{Pa}-$ cific values in some instances (e.g., 4.05 Ma). Such extremely low $\delta^{13} \mathrm{C}$ values in the deep Atlantic can only be explained by intrusion of a nutrient-rich, low $\delta^{13} \mathrm{C}$ water mass such as AABW. Because the most extreme $\delta^{13} \mathrm{C}$ minima of Site 929 correspond to glacial stages as discussed above, there appears to be a strong link between increases in the relative flux of SCW and glacial climates during the early Pliocene. The high $\delta^{13} \mathrm{C}$ variability suggests that Site 929 , unlike Site 925, was located within the mixing zone of NCW and SCW and was therefore highly sensitive to changes in relative production rates.

During isotope Stage MG $2(\sim 3.4 \mathrm{Ma})$, the horizontal $\delta^{13} \mathrm{C}$ gradient between Site 925 and Site 849 decreased to nearly half of the late Holocene gradient ( $\sim 0.45 \%$ o vs. $\sim 0.8 \%$, respectively) due to the large decrease in Site $925 \delta^{13} \mathrm{C}$ values (Fig. 10). This is consistent with the lack of a vertical $\delta^{13} \mathrm{C}$ gradient between Sites 925 and 929 due to an increase in the relative flux of SCW. Oxygen isotope Stage MG 2 is the only time that our records provide evidence for significant influence of SCW at the shallower Atlantic Site 925 during the early Pliocene interval under investigation (4.7-3.3 Ma).

\section{CONCLUSIONS}

Stable isotope stratigraphies from two vertically offset sites bounding the modern mixing zone of NADW and AABW have been constructed from the Ceara Rise depth transect to trace deep-water flow during the early Pliocene (3.3-4.6 Ma). Both records (Site 925 and 929) display $\delta^{18} \mathrm{O}$ maxima corresponding to most of the early Pliocene isotope stages between M2 and NS4 (Shackleton et al.,

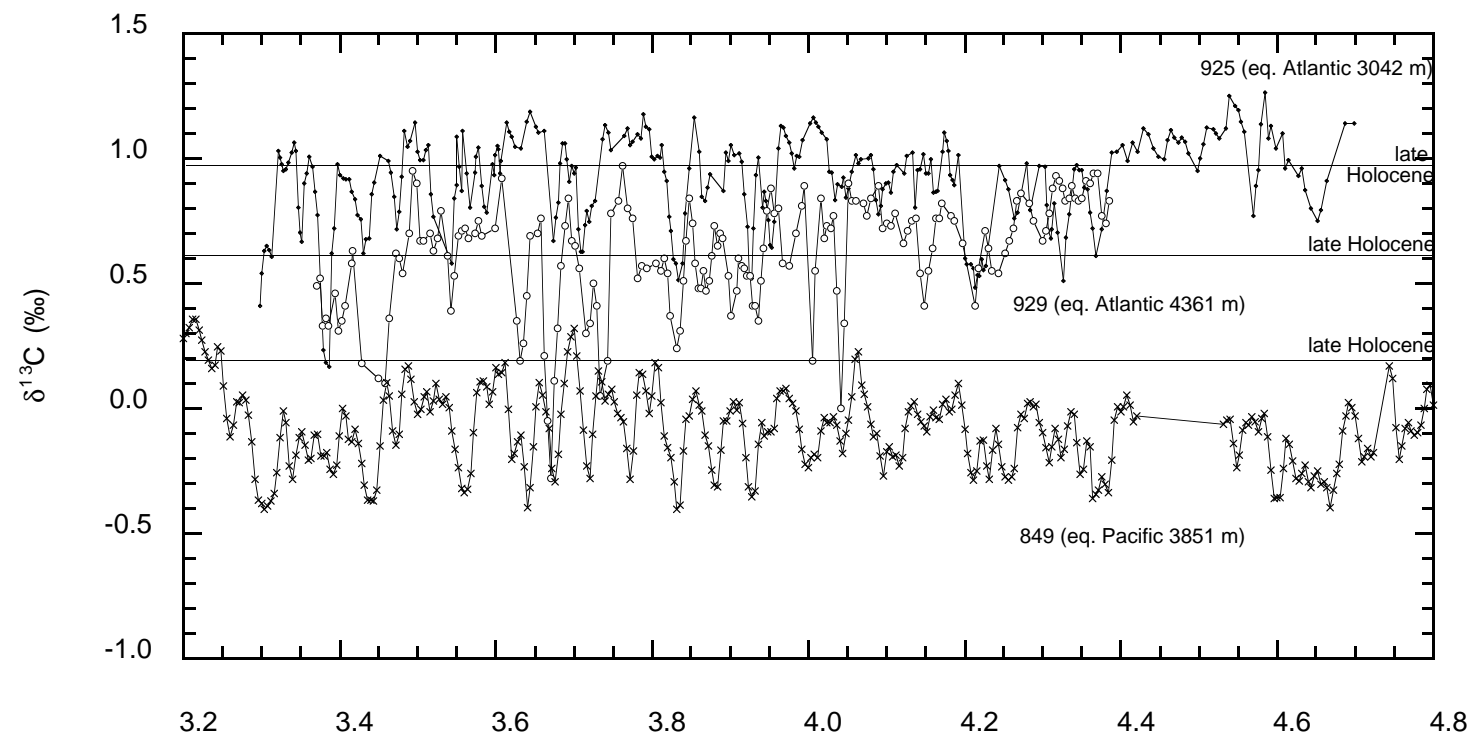

Age (Ma)

Figure 10. Horizontal $\delta^{13} \mathrm{C}$ gradients between Atlantic Sites 925, 929, and Pacific Site 849 (Mix et al., 1995). Site 849 has been smoothed with a 19 k.y. Gaussian filter (Mix et al., 1995). 
1995). Higher than expected $\delta^{18} \mathrm{O}$ values at Site 925 between 4.2 and 3.7 Ma may represent warmer and more saline source-water masses. Site $929 \delta^{18} \mathrm{O}$ values correspond well to previously published records, suggesting an average decrease in the isotopic composition of ocean water of $\sim 0.4 \%$ with respect to late Holocene. Until $3.4 \mathrm{Ma}$, only the deeper Site 929 is affected by changes in the relative fluxes of NCW vs. SCW on glacial to interglacial time scales. This is reflected by the high $\delta^{13} \mathrm{C}$ variability with extreme minima associated predominantly with glacial events. The shallower Site 925 remained within the core of NCW throughout the majority of the early Pliocene as evidenced by persistently high $\delta^{13} \mathrm{C}$ values. Not until isotope Stage MG $2(\sim 3.4 \mathrm{Ma})$ do we have evidence that SCW may have extended up to $3000 \mathrm{~m}$ water depth. Thus, the $\delta^{13} \mathrm{C}$ records from the Ceara Rise provide convincing evidence for relatively strong NCW formation during the early Pliocene. These results are consistent with climate models that attribute North Atlantic warmth to increased thermohaline circulation.

\section{ACKNOWLEDGMENTS}

We thank P. Heintz and H. Paul for assistance with sediment processing. We would also like to thank O. Osterman for help with species identification and E. Thomas for interesting discussions on Cibicidoides spp. microhabitats. We are grateful to S.-O. Franz and R. Tiedemann for their quick replies to questions concerning the age models. In addition, we thank N. Shackleton, D.A. Hodell, and D.A. Warnke for suggestions that have greatly improved this manuscript. All stable isotopic analyses were provided by the University of California, Santa Cruz Stable Isotope Laboratory under the direction of A.C. Ravelo and J.C. Zachos. This research was supported by JOI/ USSAC Grant 154-20839 and NSF Grant OCE-9458367-001 (JCZ), and by NSF Grant OCE-9510440 (ACR).

\section{REFERENCES}

Bassinot, F.C., Beaufort, L., Vincent, E., Labeyrie, L.D., Rostek, F., Müller, P.J., Quidelleur, X., and Lancelot, Y., 1994. Coarse fraction fluctuations in pelagic carbonate sediments from the tropical Indian Ocean: a 1,500k.y. record of carbonate dissolution. Paleoceanography, 9:579-600.

Boyle, E.A., and Keigwin, L., 1987. North Atlantic thermohaline circulation during the last 20,000 years linked to high-latitude surface temperature. Nature, 330:35-40.

Broecker, W.S., and Peng, T.-H., 1982. Tracers in the Sea: Palisades, NY (Eldigio Press).

Burckle, L.H., Mortlock, R., and Rudolph, S., 1996. No evidence for extreme, long term warming in early Pliocene sediments of the Southern Ocean. Mar. Micropaleontol., 27:215-226.

Crowley, T.J., 1983. Calcium carbonate preservation patterns in the central North Atlantic during the last 150,000 years. Mar. Geol., 51:1-14.

1991. Modeling Pliocene warmth. In Cronin, T.M., and Dowsett, H.J. (Eds.), Pliocene Climates. Quat. Sci. Rev., 10:275-282.

Curry, W., Duplessy, J.C., Labeyrie, L.D., and Shackleton, N.J., 1988. Changes in the distribution of $\delta^{13} \mathrm{C}$ of deepwater $\Sigma \mathrm{CO}_{2}$ between the last glaciation and the Holocene. Paleoceanography, 3:317-341.

Curry, W.B., Shackleton, N.J., Richter, C., et al., 1995, Proc. ODP, Init. Repts., 154: College Station, TX (Ocean Drilling Program).

Dowsett, H.J., Cronin, T.M., Poore, R.Z., Thompson, R.S., Whatley, R.C., and Wood, A.M., 1992. Micropaleontological evidence for increased meridional heat transport in the North Atlantic Ocean during the Pliocene. Science, 258:1133-1135.

Dowsett, H.J., and Poore, R.Z., 1991. Pliocene sea surface temperatures of the North Atlantic Ocean at 3.0 Ma. In Cronin, T.M., and Dowsett, H.J. (Eds.), Pliocene Climates. Quat. Sci. Rev., 10:189-204.

Duplessy, J.-C., Shackleton, N.J., Matthews, R.K., Prell, W., Ruddiman, W.F., Caralp, M., and Hendy, C.H., 1984. ${ }^{13} \mathrm{C}$ record of benthic foraminifers in the last interglacial ocean: implications for the carbon cycle and global deep-water circulation. Quat. Res., 21:225-243.
Farrell, J.W., 1991. Late Neogene paleoceanography of the central equatorial Pacific: evidence from carbonate preservation and stable isotopes $[\mathrm{Ph} . \mathrm{D}$. thesis]. Brown Univ., Providence, RI.

Farrell, J.W., and Prell, W.L., 1991. Pacific $\mathrm{CaCO}_{3}$ preservation and $\delta^{18} \mathrm{O}$ since $4 \mathrm{Ma}$ : paleoceanic and paleoclimatic implications. Paleoceanography, 6:485-498.

Graham, D.W., Corliss, B.H., Bender, M.L., and Keigwin, L., 1988. Carbon and oxygen isotopic disequilibria of Recent deep-sea benthic foraminifera. Mar. Micropaleontol., 6:483-497.

Hodell, D.A., and Ciesielski, P.F., 1990. Southern ocean response to the intensification of Northern Hemisphere glaciation at 2.4 Ma. In Bleil, U., and Thiede, J. (Eds.), Geological History of the Polar Oceans: Arctic versus Antarctic: (Dordrecht) Kluwer, 707-728.

Hodell, D.A., Kennett, J.P., and Leonard, K.A., 1982. Climatically induced changes in the vertical water mass structure of the Vema Channel during the Pliocene: evidence from Deep Sea Drilling Project Holes 516A, 517, and 518. In Barker, P.F., Carlson, R.L., Johnson, D.A., et al., Init. Repts. DSDP, 72: Washington (U.S. Govt. Printing Office), 907-919.

Hodell, D.A., and Venz, K., 1992. Toward a high resolution stable isotopic record of the Southern Ocean during the Pliocene-Pleistocene (4.8-0.8 Ma). In Kennett, J.P., and Warnke, D.A. (Eds.), The Antarctic Paleoenvironment: A Perspective on Global Change (Pt. 1). Am. Geophys. Union, Antarctic Res. Ser., 56:265-310.

Kennett, J.P., and Hodell, D.A., 1993. Evidence for relative climate stability of Antarctica during the early Pliocene: a marine perspective. Geogr. Ann., 75A:205-220.

Kroopnick, P.M., 1985. The distribution of $\delta^{13} \mathrm{C}$ of $\Sigma \mathrm{CO}_{2}$ in the world oceans. Deep-Sea Res., Part A, 32:57-84.

Maier-Raimer, E., Mikolajewicz, U., and Crowley, T.J., 1990. Ocean general circulation model sensitivity experiment with an open Central American isthmus. Paleoceanography, 5:349-366.

Miller, K.G., and Fairbanks, R.G., 1985. Oligocene to Miocene carbon isotope cycles and abyssal circulation changes. In Sundquist, E., and Broecker, W.S. (Eds.), The Carbon Cycle and Atmospheric $\mathrm{CO}_{2}$ : Natural Variations, Archean to Present, Geophys. Monogr., Am. Geophys. Union, 32:469-486.

Mix, A.C., Pisias, N.G., Rugh, W., Wilson, J., Morey, A., and Hagelberg, T. K., 1995. Benthic foraminifer stable isotope record from Site 849 (0-5 Ma): Local and global climate changes. In Pisias, N.G., Mayer, L.A., Janecek, T.R., Palmer-Julson, A., and van Andel, T.H. (Eds.), Proc. ODP, Sci. Results, 138: College Station, TX (Ocean Drilling Program), 371412.

Oppo, D.W., Fairbanks, R.G., and Gordon, A.L., Shackleton, N.J., 1990. Late Pleistocene Southern Ocean $\delta^{13} \mathrm{C}$ variability. Paleoceanography, 5:4354.

Oppo, D.W., Raymo, M.E., Lohman, G.P., Mix, A.C., Wright, J.D., and Prell W.L., 1995. A $\delta^{13} \mathrm{C}$ record of upper North Atlantic deep-water during the past 2.6 million years. Paleoceanography, 10:373-394.

Pickard, G.L., and Emery, W.J., 1990. Descriptive Physical Oceanography: An Introduction. (5th ed.): New York (Pergamon).

Raymo, M.E., 1994. The initiation of Northern Hemisphere glaciation. Annu. Rev. Earth Planet. Sci., 22:353-383.

Raymo, M.E., Grant, B., Horowitz, M., and Rau, G.H., 1996. Mid-Pliocene Warmth: stronger greenhouse and stronger conveyor. Mar. Micropaleontol., 21:313-326.

Raymo, M.E., Hodell, D.A., and Jansen E., 1992. Response of deep ocean circulation to initiation of Northern Hemisphere glaciation (3-2 Ma). Paleoceanography, 7:645-672.

Raymo, M.E., Ruddiman, W.F., and Clement, B.M., 1987. Pliocene-Pleistocene paleoceanography of the North Atlantic at DSDP Site 609. In Ruddiman, W.F., Kidd, R.B., Thomas, E., et al., Init. Repts. DSDP, 94: Washington (U.S. Govt. Printing Office), 895-901.

Raymo, M.E., Ruddiman, W.F., Shackleton, N.J., and Oppo, D.W., 1990. Evolution of Atlantic-Pacific $\delta^{13} \mathrm{C}$ gradients over the last 2.5 m.y. Earth Planet. Sci. Lett., 97:353-368.

Rind, D., and Chandler, M., 1991. Increased ocean heat transport and warmer climate. J. of Geophys. Res., 96:7437-7461.

Shackleton, N.J., 1977. Carbon-13 in Uvigerina: Tropical rainforest history and the equatorial Pacific carbonate dissolution cycles. In Anderson N.R., and Malahoff, A. (Eds.), The Fate of Fossil Fuel $\mathrm{CO}_{2}$ in the Oceans: New York (Plenum), 401-427.

Shackleton, N.J., and Hall, M.A., 1984. Carbon isotope data from Leg 74 sediments. In Moore, T.C., Jr., Rabinowitz, P.D., et al., Init. Repts. DSDP, 74: Washington (U.S. Govt. Printing Office) 613-619. 
Shackleton, N.J., Hall, M.A., and Pate, D., 1995. Pliocene stable isotope stratigraphy of Site 846. In Pisias, N.G., Mayer, L.A., Janecek, T.R., Palmer-Julson, A., and van Andel, T.H. (Eds.), Proc. ODP, Sci. Results, 138: College Station, TX (Ocean Drilling Program), 337-355.

Shackleton, N.J., and Opdyke, N.D., 1973. Oxygen isotope and paleomagnetic stratigraphy of equatorial Pacific core V28-238: oxygen isotope temperatures and ice volumes on a $10^{5}$ year and $10^{6}$ year scale. Quat. Res. (N.Y.), 3:39-55.

Shackleton, N.J., Wiseman, J.D.H., and Buckley, H.A., 1973. Nonequilibrium isotopic fractionation between seawater and planktonic foraminiferal tests. Nature, 242:177-179.

Tiedemann, R., Sarnthein, M., and Shackleton, N.J., 1994. Astronomic timescale for the Pliocene Atlantic $\delta^{18} 0$ and dust flux records of Ocean Drilling Program Site 659. Paleoceanography, 9:619-638.

Washington, W.M., and Meehl, G.A., 1989. Climate sensitivity due to increased $\mathrm{CO}_{2}$ : experiments with a coupled atmosphere and ocean general circulation model. Climate Dynamics, 4:1-38.
Webb, P.-N., and Harwood, D.M., 1991. Late Cenozoic glacial history of the Ross Embayment, Antarctica. In Cronin, T.M., and Dowsett, H.J. (Eds.), Pliocene Climates. Quat. Sci. Rev., 10:215-223.

Woodruff, F., and Savin, S.M., 1991. Mid-Miocene isotope stratigraphy in the deep sea: high resolution correlations, paleoclimatic cycles, and sediment preservation. Paleoceanography, 6:755-806.

Woodruff, F., Savin, S.M., and Douglas, R.G., 1980. Biological fractionation of oxygen and carbon isotopes by Recent benthic foraminifera. Mar. Micropaleontol., 5:3-11.

Wright, J.D., Miller, K.G., and Fairbanks, R.G., 1991. Evolution of modern deepwater circulation: Evidence from the late Miocene Southern Ocean. Paleoceanography, 6:275-290.

Date of initial receipt: 4 December 1995

Date of acceptance: 16 August 1996

Ms 154SR-115 